DOI: 10.46340/eppd.2020.7.3.10

Daria Balobanova, PhD in Law

ORCID ID: https://orcid.org/0000-0001-7247-0560

National University "Odesa Law Academy", Ukraine

\title{
CRIMINAL LAW POLICY AS THE LEVEL OF CRIMINAL LAW DYNAMICS: INTERNAL AND EXTERNAL ASPECTS
}

\author{
Дар'я Балобанова, к. ю. н. \\ Національний університет "Одеська юридична академія», Україна \\ КРИМІНАЛЬНО-ПРАВОВА ПОЛІТИКА \\ ЯК РІВЕНЬ ДИНАМІКИ КРИМІНАЛЬНОГО ПРАВА: \\ ВНУТРІШНІЙ ТА ЗОВНІШНІЙ АСПЕКТИ
}

\begin{abstract}
Criminal law policy is the primary level of national criminal law dynamics, a certain system of defined goals, directions, and guidelines for its development, regardless of its enshrinement in autonomous normative documents of a strategic nature. Criminal law policy is implemented in two directions - internal and external. Internal criminal law policy proceeds within the Constitution of the state. The external (international) criminal law policy of the state proceeds in the frameworks of global international acts, international treaties of states that have been ratified in the prescribed way, and must fully comply with the Constitution. Criminal law policy, as a level of dynamics of criminal law, should demonstrate the continuity of national criminal law and the consistency with the norms of national law and with the requirements of international standards and international treaties of Ukraine.
\end{abstract}

Keywords: criminal law policy, dynamics of criminal law, internal criminal law policy, international criminal law policy.

Актуальність теми дослідження. Кримінально-правова політика, як тактико-стратегічний компонент державної правової політики, володіє важливою для кримінального права в цілому місією - саме нею визначаються офіційні напрями змін кримінального права.

I хоча достатньо довго інститут кримінально-правової політики на теренах України був з3овні ідеологізований, але все одно він здійснював певний вплив на розвиток кримінального права. Саме ті парадигми, які обиралися кримінально-правовою політикою, підіймалися і підіймаються зараз «на гасла», виступають настановами кримінально-правової політики, i, відповідно, стають реальними чи фіктивними напрямками розвитку кримінального права і, відповідно, правореалізації. За відсутності ідеологізації кримінального права, кримінально-правова політика, як вчення, набуває для суспільства особливої цінності, повертаючи собі привілей керування динамікою кримінального права, визначення напрямів його розвитку в демократичному суспільстві.

Стан дослідження. Загальним питанням кримінально-правової політики України (iї визначення, зміст, ознаки тощо) та її проявам в різних аспектах протидії окремим формам злочинної поведінки присвячені праці таких сучасних вчених в галузі кримінального права, як Ю.В. Бауліна, B.I. Борисова, В.К. Грищука, I.В. Козича, О.О. Житного, Є.В. Лащука, К.Б. Марисюка, А.А. Мітрофанова, А.А. Музики, Ю.А. Пономаренка, Н.А. Савінової, Є.Л. Стрельцова, В.О. Тулякова, П.Л. Фріса та ін.

Метою статті є визначення ролі кримінально-правової політики держави як рівня динаміки кримінального права з урахуванням внутрішньої та зовнішньої ії характеристики.

Виклад основних положень. На думку П.Л. Фріса, засновника сучасного вітчизняного вчення про кримінально-правову політику, вона $є$ «системоутворюючим елементом політики у сфері боротьби із злочинністю, яка являє собою вироблену Українською державою генеральну лінію, що визначає основні напрями, цілі і засоби впливу на злочинність шляхом формування кримінального, кримінально-процесуального та кримінально-виконавчого законодавства, регулювання практики ї 
застосування, а також розробку й реалізацію заходів, направлених на попередження злочинів»1. Важливо, що ідея генеральної лінії, а не обов'язкових стратегічних виписаних документів, визначається П.Л. Фрісом як основне змістовне наповнення оболонки такої політики.

Адже, «не політика у своєму русі йде за правом, пристосовуючись до його логіки і системи, а, навпаки, право розвивається у напрямі вироблених політичних установок, в реалізації яких воно повинне брати участь», i «кримінальна політика знаходить своє вираження у відповідних законах та інших нормативно-правових актах, концепціях, програмах. У найбільш концентрованому вигляді вона фокусується у кримінальному законі» ${ }^{2}$. Хоча сьогодні зустрічаються прибічники іншого підходу до оцінки кримінально-правової політики, зокрема, в частині оцінки ії як системи ідей і настанов $^{3}$, що дещо поширює розуміння кримінально-правової політики.

Але, на нашу думку, в даному випадку кримінально-правову політику слід бачити як первинний рівень динаміки національного кримінального права, певну систему визначених цілей, напрямків та настанов щодо його розвитку, незалежно від того, чи закріплена вона в самостійних нормативних документах стратегічного характеру, чи ні.

Традиційно у вітчизняній кримінально-правовій науці кримінально-правова політика 3 різними акцентами, але однаково за сутністю, розумілася як політика внутрішня. Це повною мірою обгрунтовано - майже всі відповідні дослідження здійснювалися до етапу захоплення країн на теренах колишнього СРСР загальносвітовими глобалізаційними процесами, а отже питання кримінального права, за виключенням міжнародного кримінального права, було прерогативою держави в закритому суспільстві.

Більш коректним $є$ визначення внутрішньої кримінально-правової політики 3 точки зору підпорядкування іiі Конституції, а не вираження іiі через Конституцію. На жаль, роль Конституції сьогодні, в умовах можливості іiі змін та подекуди сумнівних тлумачень, нівелюється. Утім, у суспільстві, що ставиться до неї як до дійсно Основного закону, Конституція є нерухомим стрижнем для політики, нових еліт, міжнародних угод тощо. Вона $\epsilon$ гарантією суверенітету, прав людини і провідною лінією розвитку правової політики та ії гілок, i, відповідно, динаміки. Отже, внутрішня кримінально-правова політика, які і будь-який інший різновид внутрішньої правової політики, діє в межах Конституції держави.

Останнім часом на визначення кримінально-правової політики та розуміння іï змісту почали впливати фактори глобалізації та євроінтеграційних процесів, умови Асоціації Україна-Свропа ${ }^{4}$. При цьому, й А.А. Музика та Є.В. Лащук ${ }^{5}$, й О.О. Житний ${ }^{6}$ наполягають на тому, що міжнародна кримінально-правова політика базується не на міжнародній правовій політиці, а на глобальних потребах у протидії злочинності, наявних міжнародних правових приписах та доктрині права.

Справедливими $є$ й слова П.Л. Фріса стосовно особливостей впливу міжнародних критеріїв на внутрішню кримінально-правову політику: «визначаючи власну кримінально-правову політику держава все частіше вимушена «оглядатися» на своїх партнерів по міжнародним організаціям, прислуховуватися до їх позиції, враховувати їі» ${ }^{7}$. Але не безумовно підкорятися або копіювати! Це $\epsilon$

\footnotetext{
${ }^{1}$ Фріс, П.Л. (2005). Кримінально-правова політика Української держсави: теоретичні, історичні та правові проблеми. Київ: Атіка, 393.

2 Узунова, О.В., Узунов, П.П. (2006). Міжнародні договори України як джерела кримінально-правової політики. Кримінально-правова політика держави: теоретичні та практичні аспекти проблеми: матеріали міжнародної наукової конференції (17-18 листопада 2006 р., м. Донецьк). Донецьк, 127-128.

${ }^{3}$ Куц, В.М. (2006). Деякі аспекти вдосконалення національної кримінально-правової політики. Кримінальноправова політика держави: теоретичні та практичні аспекти проблеми: матеріали міжнародної наукової конференції (17-18 листопада 2006 р., м. Донецьк). Донецьк, 48.

${ }^{4}$ Угода про Асоиіацію між Україною, з однієї сторони, та Свропейським Союзом, Свропейським співтовариством з атомної енергії і їхніми державами-членами, з іншої сторони 2014. Відомості Верховної Ради України, 40, 2021.

${ }^{5}$ Музика, А.А., Лащук, С.В. (2008). Про міжнародну кримінально-правову політику як новий та перспективний напрям наукових досліджень. Наука і правоохорона, 2 (8), 21-33.

6 Житний, О.О. (2015). Міжнародний вимір кримінально-правової політики (підстави виникнення, перспективи розвитку). Право і суспільство, 2, 54-60.

7 Фріс, П.Л. (2011). Кримінально-правова політика України на шляху до Свроінтеграції. 10 років чинності Кримінального кодексу України: проблеми застосування, удосконалення та подальшої гармонізації із законодавством європейських країн: матеріали міжнародної науково-практичної конференції (13-14 жовтня 2011 р., м. Харків). Харків, 89.
} 
додатковим аргументом на користь недопустимості бездумної уніфікації законодавства на шкоду власним внутрішнім інтересам.

Міжнародна кримінально-правова політика - поняття багатогранне. Це і явище, яке включає взаємодію всіх акторів, і конкретна політична позиція певного актора у взаємодії з іншими. В тому контексті, який важливий для дослідження динаміки кримінального права, може йтися про міжнародну кримінально-правову політику держави в політичному полі міжнародного співтовариства. Утім, і така політика залежить від міжнародних нормативних актів глобального значення, або від міжнародних угод держави, рішення про приєднання до яких приймаються у межах конституційних повноважень відповідними органами влади.

Таким чином, і зовнішня (міжнародна) кримінально-правова політика держави діє в межах глобальних міжнародних актів, міжнародних договорів країни, які ратифіковані у встановленому порядку, і повністю має відповідати Конституції.

Сьогодні дослідники всіх сфер кримінально-правової політики (П.Л. Фріс, Н.А. Савінова, А.А. Митрофанов, К.Б. Марисюк та ін.) вважають необхідною розробку пріоритетів такої політики для подальшого розвитку кримінального права на базі їі настанов.

Нами було проведене опитування фахівців у сфері кримінального права та на їх думку саме політико-правові механізми $є$ найбільш впливовими на динаміку кримінального права (50,5\% опитаних), тоді як соціально-економічні фактори є визначальними на думку 44\% опитаних, культурологічні - $1,8 \%$, всі разом - $1,8 \%$.

Політико-правові механізми впливу респонденти розподілили за значущістю наступним чином (припускалося обрання декількох варіантів відповідей):

1. зміна політичних еліт (79,8\%);

2. вплив правозастосовної практики $(58,7 \%)$;

3. вплив рішень наддержавних інституцій $(48,6 \%)$;

4. зміна форм правління $(24,8 \%)$;

5. зміна форм державного устрою (20,2\%).

Той факт, що зміна політичних еліт, в порівнянні з іншими факторами впливу на кримінальне право, поставлена на перше місце, свідчить про те, що кримінально-правова політика, яку несуть такі еліти, $\epsilon$, дійсно, головною рушійною силою динаміки кримінального права. I не має значення, визначена вона на рівні спеціальних нормативних документів, чи ні, адже політична складова і $€$ головним генератором ідей впровадження тих чи інших змін до Кримінального кодексу (далі - КК).

Водночас, кримінально-правова політика, як рівень динаміки кримінального права, має демонструвати наступність у національному кримінальному праві і узгодженість як з нормами національного права, так і з вимогами міжнародних стандартів та міжнародних договорів України.

Загальна світова інтеграція країн і народів не може не вплинути самим прямим чином на розвиток внутрішнього правопорядку в цих країнах. Актуальність міжнародного співробітництва в реалізації завдань кримінальної політики обумовлюється тим, що, за твердженням В.В. Лунеева, «найбільшою небезпекою для людства, його демократичного і економічного розвитку залишається інтенсивно зростаюча національна і транснаціональна злочинність, яка в даний час включає в себе i традиційно кримінальні, і військові, і екологічні, і генетичні, та інші загрози» ${ }^{1}$.

О.О. Дудоров та Т.M. Тертиченко зазначають, що незважаючи на те, що довгий час у науці кримінального права превалювала думка про опосередкований зв'язок міжнародного та кримінального права, наразі, з огляду на процеси глобалізації у світі, які сприяють поступовому підвищенню рівня універсалізації національних законодавств країн світу, ситуація кардинально змінюється. I Україна в цьому випадку не стала винятком, в тому числі й в кримінальному праві ${ }^{2}$

У 2014 р. О.О. Дудоров та М.I. Хавронюк, описуючи зміст реалізації принципу верховенства права, писали: «пріоритет в суспільстві, насамперед, мають права людини; відносини між державою та особою регулюються на основі принципу: «Особі дозволено чинити все, що прямо не заборонено

\footnotetext{
${ }^{1}$ Лунеев, В.В. (2005). Преступность ХХ века: мировые, региональные и российские тенденичи. Москва: Волтерс Клувер, 8-9.

2 Дудоров, О.О., Тертиченко, Т.М. (2014). Обумовленість удосконалення кримінального законодавства України законодавством Ради Свропи та Європейського Союзу. Наука кримінального права в системі міждисциплінарних зв'язків: матеріали міжнародної науково-практичної конференції (9-10 жовтня 2014 р., м. Харків). Харків, 90.
} 
законом»; будь-яке свавілля і дискримінація заборонені; усі є вільними і рівними у своїх правах; кожному забезпечується доступ до правосуддя у незалежних та неупереджених судах; включаючи перегляд судом законів. Суд застосовує принцип верховенства права з урахуванням судової практики ЄСПЛ» ${ }^{1}$ Такий підхід багато років пробивав собі дорогу на рівні кримінально-правової політики, і саме через неї знайшов своє відображення на рівні застосування законодавства, i, зокрема, в рішеннях судів.

Кримінальна політика СС своїм корінням сягає в національний правопорядок, відповідно в якості джерел європейської союзної кримінальної політики слід називати внутрішню політику країн - членів ЄС. Узгодженість волевиявлення держав при розробці норм міжнародного права має на увазі, перш за все, відповідність даних норм внутрішнім правопорядкам, від яких залежить позиція представників країн. Тому багато країн в своїх конституціях закріпили положення про примат міжнародно-правових норм над внутрішніми, так як вони розуміють, що такі норми, відповідним чином прийняті, ніяк не можуть суперечити внутрішньому правопорядку.

Відповідно до ч. 1 ст. 3 КК України, «законодавство України про кримінальну відповідальність утворює Кримінальний кодекс України, який грунтується на Конституції України і визнаних принципах і нормах міжнародного права». Крім того, ч. 5 ст. 3 КК закріплює положення про те, що «закони України про кримінальну відповідальність повинні відповідати положенням, що містяться в чинних міжнародних договорах, згоду на обов'язковість яких дала Верховна Рада України».

Дані положення грунтуються на вимозі, закріпленій в ч. 1 ст. 9 Конституції України, яка передбачає, що «чинні міжнародні договори, згода на обов'язковість яких надана Верховною Радою України, $є$ частиною національного законодавства України».

У КК України існують норми, застосування яких неможливо без звернення до норм міжнародного права, заснованих на загальних тенденціях європейської кримінальної політики. Це відноситься до дії кримінального закону в просторі (ст. 6 КК), відповідальності дипломатичних представників іноземних держав та інших громадян, які користуються імунітетом (ч. 4 ст. 6 КК), відповідальності іноземних громадян за низку злочинів, скоєних за кордоном (ст. 8 КК), видачі іноземних громадян і осіб без громадянства, які вчинили злочин за кордоном (ст. 10 КК), та ін. В КК України містяться склади так званих «конвенційних» злочинів, тобто таких, загальні ознаки і принципи відповідальності за які передбачені в міжнародних угодах (конвенціях), ратифікованих Україною. До числа таких складів відносяться торгівля людьми (ст. 149 КК), тероризм (ст.ст. 258-258 КК), незаконний обіг наркотиків і психотропних речовин (Розділ XIII Особливої частини КК), викрадення повітряного або водного судна (ст. 278 КК) та ін. Крім цього, в КК встановлена відповідальність і за ряд міжнародних злочинів, тобто злочинів, які посягають на безпеку всього людства і протидія яким здійснюється усіма країнами - членами спільноти: геноцид (ст. 442 КК), екоцид (ст. 441 КК), найманство (ст. 447 КК), воєнні злочини (ст.ст. 436-440 КК).

Таким чином, слід відзначити зв'язок загальноєвропейської кримінальної політики та кримінальної політики кожної держави, як тих, що вже входять в співтовариство, так й тих, які прагнуть цього досягти.

Провідними українськими вченими наголошується на тому, що «ми іноді не приділяємо належної уваги перевіреному століттями зарубіжному досвіду з тих чи інших питань» ${ }^{2}$ «інтеграція України в європейські структури ставить питання про зближення українського національного i європейського права», яке можна визначити як «сукупність правових норм, що містяться в актах практично всіх європейських міжнародних організацій», зокрема Ради Європи та Європейського Союзу $^{3}$; «через втілення в законодавстві України норм і принципів міжнародного права наша країна практично гармонізує свою правову систему не лише 3 міжнародно-правовою, а й з національними

\footnotetext{
${ }^{1}$ Дудоров, О.О., Хавронюк, М.I. (2014). Кримінальне право: навчальний посібник. Київ: Ваіте, 70.

2 Шемшученко, Ю.С. (2000). Гармонизация законодательства Украины с международным европейским правом. Европа, Япония, Украина: пути демократизации государственно-правовых систем: материалы Международной научной конференции (17-20 октября 2000 г., г. Киев). Киев, 13.

${ }^{3}$ Шемшученко, Ю.С. (1998). Европейское право: теория и практика. Проблемы гармонизации законодательства Украины с международным правом: материалы научно-практической конференции (г. Киев). Киев, 26.
} 
правовими системами окремих держав світу» ${ }^{1}$ процесу міждержавного співробітництва «істотно заважає існуючі відмінності національних правових систем, їх нездатність до швидкої адаптації до міжнародно-правових», а тому «актуалізується необхідність створення єдиного правового простору, в межах якого можна було б швидше досягти ефективної співпраці між державами, що мають різні ... правові системи» ${ }^{2}$; «зближення правових систем європейських держав в даний час $€$ найважливішою традицією формування галузей національного права і галузей національного законодавства» ${ }^{3}$.

Одним з епохальних рішень для правової, та, безумовно, кримінально-правової політики сьогоднішньої України з серпня 2019 р. $є$ робота Комісії з правової реформи, в межах якої розвитком кримінального законодавства займається відповідна робоча група на чолі з академіком Ю.В. Бауліним ${ }^{4}$.

Вказана робоча група включає провідних фахівців з кримінального права, зусилля яких спрямовані саме (також!) на розвиток кримінального права. Усвідомлення такого кроку як реформа в кримінальному праві - різкі реакції революційного типу вже довели свою неефективність та провокативність, і тому члени робочої групи з розвитку кримінального права, фактично, намагаються провести модернізацію кримінального права, з урахуванням вимог міжнародної та національної кримінально-правової політики.

Думки щодо доцільності змін та характеру цих змін до КК України висловили респонденти в процесі проведеного нами опитування. Безумовна більшість $(91,7 \%)$ вважає за доцільне внесення змін до КК України та необхідність зробити це шляхом прийняття нового кодексу підтримує 45\% опитаних. Отже, створення групи з розвитку кримінального права $є$ доволі логічним державницьким рішенням.

Висновки. Кримінально-правова політика, як тактико-стратегічний компонент державної правової політики, визначає офіційні напрями змін кримінального права.

Праці, що утворювали вчення про кримінально-правову політику з початку виокремлення іiі проблем як самостійної наукової галузі, об'єднували вчених у розумінні того, що кримінальноправова політика $є$ основною направляючою подальшого руху законодавчої та правозастосовчої практик розвиту кримінального права. Факт нівелювання вчення про кримінально-правову політику в період тоталітарної ідеологізації кримінального права (радянський період) певною мірою зрозумілий: фактично радянська ідеологія виступала стрижнем формулювання кримінальноправових приписів. За відсутності ідеологізації кримінального права, кримінально-правова політика, як вчення, набуває для суспільства особливої цінності, повертаючи собі привілей керування динамікою кримінального права, визначення напрямів його розвитку в демократичному суспільстві.

Кримінально-правова політика реалізується в двох напрямах: внутрішня та зовнішня кримінально-правова політика. Внутрішня кримінально-правова політика, які і будь-який інший різновид внутрішньої правової політики, діє в межах Конституції держави. Зовнішня (міжнародна) кримінально-правова політика держави діє в межах глобальних міжнародних актів, міжнародних договорів країни, які ратифіковані увстановленому порядку, i повністю має відповідати Конституції.

Кримінально-правова політика, як первинний рівень динаміки кримінального права, має демонструвати наступність у національному кримінальному праві і узгодженість як з нормами національного права, так і з вимогами міжнародних стандартів та міжнародних договорів України. На сучасному етапі кримінально-правова політика України перебуває в кульмінаційному моменті, коли підготовка проекту нового кримінального кодексу є довгоочікуваною спробою остаточно

\footnotetext{
${ }^{1}$ Опришко, В.Ф. (1998). Теоретические и практические аспекты механизма гармонизации законодательства Украины с международным правом. Проблемы гармонизащии законодательства Украины с международнылм правом: материалы научно-практической конференции (г. Киев). Киев, 14.

${ }^{2}$ Опришко, В.Ф. (2000). Проблема сближения европейского права с законодательством Украины. Eвропа, Япония, Украина: пути демократизаџии государственно-правовых систем: материалы Международной научной конференции (17-20 октября 2000 г., г. Киев). Киев, 38.

${ }^{3}$ Таций, В.Я., Грошевой, Ю.М. (1998). Проблемы сближения европейских правовых систем как условие гармонизации законодательства Украины. Проблемы гармонизащии законодательства Украинь с международным правом: материалы научно-практической конференции (г. Киев). Киев, 53-54.

${ }^{4}$ Питання Комісії з правової реформи 2019 (Президент України). Урядовий кур’єр, 153.
} 
відійти від попередньої парадигми «пострадянського» кримінального права як засобу боротьби зі злочинністю i перевести його у якість галузі права, що намагається протидіяти найбільш небезпечним проявам людської поведінки.

\section{References:}

1. Dudorov, O.O., Tertychenko, T.M. (2014). Obumovlenist udoskonalennia kryminalnoho zakonodavstva Ukrainy zakonodavstvom Rady Yevropy ta Yevropeiskoho Soiuzu [Conditionality of improvement of the criminal legislation of Ukraine by the legislation of the Council of Europe and the European Union]. Nauka kryminalnoho prava $v$ systemi mizhdystsyplinarnykh zviazkiv: materialy mizhnarodnoi naukovo-praktychnoi konferentsii (9-10 zhovtnia 2014 r., m. Kharkiv) [The science of criminal law in the system of interdisciplinary relations: proceedings of the International scientific-practical conference (October 9-10, 2014, Kharkiv)]. Kharkiv, 90. [in Ukrainian].

2. Dudorov, O.O., Khavroniuk, M.I. (2014). Kryminalne pravo: navchalnyi posibnyk [Criminal law: a textbook]. Kyiv: Vaite. [in Ukrainian].

3. Zhytnyi, O.O. (2015). Mizhnarodnyi vymir kryminalno-pravovoi polityky (pidstavy vynyknennia, perspektyvy rozvytku) [International dimension of criminal law policy (grounds, prospects for development)]. Pravo $i$ suspilstvo [Law and society], no. 2, 54-60. [in Ukrainian].

4. Kuts, V.M. (2006). Deiaki aspekty vdoskonalennia natsionalnoi kryminalno-pravovoi polityky [Some aspects of improving the national criminal law policy]. Kryminalno-pravova polityka derzhavy: teoretychni ta praktychni aspekty problemy: materialy mizhnarodnoi naukovoi konferentsii (17-18 lystopada 2006 r., m. Donetsk) [Criminal law policy of the state: theoretical and practical aspects of the problem: proceedings of the international scientific conference (November 17-18, 2006, Donetsk)]. Donetsk, 48. [in Ukrainian].

5. Luneev, V.V. (2005). Prestupnost' XX veka: mirovye, regional'nye i rossijskie tendencii [Crime of the twentieth century: global, regional and Russian trends]. Moscow: Volters Kluver. [in Russian].

6. Muzyka, A.A., Lashchuk, Ye.V. (2008). Pro mizhnarodnu kryminalno-pravovu polityku yak novyi ta perspektyvnyi napriam naukovykh doslidzhen [On international criminal law policy as a new and promising area of research]. Nauka i pravookhorona [Science and law enforcement], no. 2 (8), 21-33. [in Ukrainian].

7. Oprishko, V.F. (1998). Teoreticheskie i prakticheskie aspekty mehanizma garmonizacii zakonodatel'stva Ukrainy $\mathrm{s}$ mezhdunarodnym pravom [Theoretical and practical aspects of the mechanism of harmonization of Ukrainian legislation with international law]. Problemy garmonizacii zakonodatel'stva Ukrainy s mezhdunarodnym pravom: materialy nauchno-prakticheskoj konferencii (g. Kiev) [Problems of harmonization of Ukrainian legislation with international law: proceedings of a scientific-practical conference (Kyiv)]. Kyiv, 14. [in Russian].

8. Oprishko, V.F. (2000). Problema sblizhenija evropejskogo prava s zakonodatel'stvom Ukrainy [The problem of approximation of European law with the legislation of Ukraine]. Evropa, Japonija, Ukraina: puti demokratizacii gosudarstvenno-pravovyh sistem: materialy Mezhdunarodnoj nauchnoj konferencii (17-20 oktjabrja $2000 \mathrm{~g}$., g. Kiev) [Europe, Japan, Ukraine: ways of democratization of state-legal systems: proceedings of the International Scientific Conference (October 17-20, 2000, Kyiv)]. Kyiv, 38. [in Russian].

9. Pytannia Komisii z pravovoi reformy 2019 [Issues of the Legal Reform Commission] (Prezydent Ukrainy) [(President of Ukraine)]. Uriadovyi kurier [Government courier], 153. [in Ukrainian].

10. Tacij, V.Ja., Groshevoj, Ju.M. (1998). Problemy sblizhenija evropejskih pravovyh sistem kak uslovie garmonizacii zakonodatel'stva Ukrainy [Problems of rapprochement of European legal systems as a condition for harmonization of Ukrainian legislation]. Problemy garmonizacii zakonodatel'stva Ukrainy s mezhdunarodnym pravom: materialy nauchno-prakticheskoj konferencii (g. Kiev) [Problems of harmonization of Ukrainian legislation with international law: proceedings of a scientific-practical conference (Kyiv)]. Kyiv, 53-54. [in Russian].

11. Uhoda pro Asotsiatsiiu mizh Ukrainoiu, z odniiei storony, ta Yevropeiskym Soiuzom, Yevropeiskym spivtovarystvom z atomnoi enerhii i yikhnimy derzhavamy-chlenamy, z inshoi storony 2014 [Association Agreement between Ukraine, of the one part, and the European Union, the European Atomic Energy Community and their Member States, of the other part]. Vidomosti Verkhovnoi Rady Ukrainy [Information of the Verkhovna Rada of Ukraine], 40, 2021. [in Ukrainian].

12. Uzunova, O.V., Uzunov, P.P. (2006). Mizhnarodni dohovory Ukrainy yak dzherela kryminalno-pravovoi polityky [International treaties of Ukraine as a source of criminal law policy]. Kryminalno-pravova polityka derzhavy: teoretychni ta praktychni aspekty problemy: materialy mizhnarodnoi naukovoi konferentsii (17-18 lystopada 2006 r., m. Donetsk) [Criminal law policy of the state: theoretical and practical aspects of the problem: proceedings of the international scientific conference (November 17-18, 2006, Donetsk)]. Donetsk, 127-128. [in Ukrainian].

13. Fris, P.L. (2005). Kryminalno-pravova polityka Ukrainskoi derzhavy: teoretychni, istorychni ta pravovi problemy [Criminal law policy of the Ukrainian state: theoretical, historical and legal problems]. Kyiv: Atika. [in Ukrainian].

14. Fris, P.L. (2011). Kryminalno-pravova polityka Ukrainy na shliakhu do Yevrointehratsii [Criminal law policy of Ukraine on the way to European integration]. 10 rokiv chynnosti Kryminalnoho kodeksu Ukrainy: problemy zastosuvannia, udoskonalennia ta podalshoi harmonizatsii iz zakonodavstvom yevropeiskykh krain: materialy mizhnarodnoi naukovo-praktychnoi konferentsii (13-14 zhovtnia 2011 r., m. Kharkiv). Kharkiv. [in Ukrainian]. 
15. Uzunova, O.V., Uzunov, P.P. (2006). Mizhnarodni dohovory Ukrainy yak dzherela kryminalno-pravovoi polityky [International treaties of Ukraine as a source of criminal law policy]. Kryminalno-pravova polityka derzhavy: teoretychni ta praktychni aspekty problemy: materialy mizhnarodnoi naukovoi konferentsii (17-18 lystopada 2006 r., m. Donetsk) [Criminal law policy of the state: theoretical and practical aspects of the problem: proceedings of the international scientific conference (November 17-18, 2006, Donetsk)]. Donetsk, 127-128. [in Ukrainian].

16. Fris, P.L. (2005). Kryminalno-pravova polityka Ukrainskoi derzhavy: teoretychni, istorychni ta pravovi problemy [Criminal law policy of the Ukrainian state: theoretical, historical and legal problems]. Kyiv: Atika. [in Ukrainian].

17. Fris, P.L. (2011). Kryminalno-pravova polityka Ukrainy na shliakhu do Yevrointehratsii [Criminal law policy of Ukraine on the way to European integration]. 10 rokiv chynnosti Kryminalnoho kodeksu Ukrainy: problemy zastosuvannia, udoskonalennia ta podalshoi harmonizatsii iz zakonodavstvom yevropeiskykh krain: materialy mizhnarodnoi naukovo-praktychnoi konferentsii (13-14 zhovtnia 2011 r., m. Kharkiv) [10 years of the Criminal Code of Ukraine: problems of application, improvement and further harmonization with the legislation of European countries: proceedings of the international scientific-practical conference (October 13-14, 2011, Kharkiv)]. Kharkiv, 89. [in Ukrainian].

18. Shemshuchenko, Ju.S. (1998). Evropejskoe pravo: teorija i praktika [European law: theory and practice]. Problemy garmonizacii zakonodatel'stva Ukrainy s mezhdunarodnym pravom: materialy nauchno-prakticheskoj konferencii (Kyiv) [Problems of harmonization of Ukrainian legislation with international law: proceedings of the scientific-practical conference (Kyiv)]. Kyiv, 26. [in Russian].

19. Shemshuchenko, Ju.S. (2000). Garmonizacija zakonodatel'stva Ukrainy s mezhdunarodnym evropejskim pravom [Harmonization of Ukrainian legislation with international European law]. Evropa, Japonija, Ukraina: puti demokratizacii gosudarstvenno-pravovyh sistem: materialy Mezhdunarodnoj nauchnoj konferencii (17-20 oktjabrja 2000 g., g. Kiev) [Europe, Japan, Ukraine: ways of democratization of state-legal systems: proceedings of the International Scientific Conference (October 17-20, 2000, Kyiv)]. Kyiv, 13. [in Russian]. 